\title{
Odnos osobnih prava vjernika u Crkvi i temeljnih ljudskih prava
}

\author{
Marija Džinić *
}

\begin{abstract}
Sažetak
Klasifikacija osobnih prava vjernika u Crkvi jedna je od većih novina Zakonika kanonskoga prava iz 1983. godine. Veliki utjecaj na pokretanje toga pitanja imao je, u prvom redu, Drugi vatikanski koncil. Iščitavajući dokumente Koncila, jasno se očituje zahtjev za uvažavanjem ne samo obveza, nego i prava vjernika u Katoličkoj crkvi. Ništa manje doprinosa nije ostavila ni Opća deklaracija o ljudskim pravima, dokument koji u svoj centar stavlja ljudsko dostojanstvo, na koje poziva i nauk Crkve. Analizirajući odnos osobnih prava vjernika u Crkvi te ljudskih prava općenito, autorica pokušava ukazati na međusobne sličnosti i različitosti tih dvaju sustava.
\end{abstract}

Ključne riječi: prava vjernika; ljudska prava; Opća deklaracija o ljudskim pravima; Drugi vatikanski koncil; Zakonik kanonskoga prava; Božji narod

\section{Uvod}

Pitanje normiranja svojevrsnoga "kataloga" prava i obveza vjernika u Crkvi, analogno normiranju ljudskih prava te temeljnih prava građana u modernim građanskim ustavima, intenzivnije je pokrenuto tek nakon Drugoga vatikanskoga koncila. Veliki utjecaj na pokretanje toga pitanja imala je Opća deklaracija o ljudskim pravima iz 1948. godine. Analizirajući njezine filozofske i političke korijene neosporno se može ustvrditi kako je riječ o dokumentu koji je temeljno laičkoga i personalističkoga karaktera. Ljudsko dostojanstvo, temelj deklaracije, svoje prvotne korijene i najsavršenije očitovanje polaže na Kristu i Evanđelju. Jednako su tako i osobna prava vjernika utemeljena na ljudskom dostojanstvu i jednakosti svih članova Crkve. Posljedično, ljudska prava pripadaju i imaju kanonsku važnost u mjeri u kojoj odgovaraju poslanju Crkve. Bitno je ipak pri analizi i usporedbi prava građana i prava vjernika naznačiti sličnosti, ali i razlike

* Dr. sc. Marija Džinić, Fakultet filozofije i religijskih znanosti. Adresa: Jordanovac 110, 10000 Zagreb. ORCID iD: https://orcid.org/0000-0001-5385-5860. E-adresa: m.dzinic@ffrz.hr 
dvaju sustava. Jedino na taj način moguće je shvatiti njihov međusobni odnos te specifičnost kanonskoga uređenja osobnih prava vjernika.

Već sam pokušaj spajanja dvaju termina: osobna prava, s jedne strane, i kanonsko pravo, s druge, otvara brojna pitanja. Prvo je svakako ono koje se odnosi na samo postojanje spomenutih prava u pravnom uređenju Katoličke crkve. Ako se poteškoćama definiranja samoga koncepta osobnih prava pridruži njihova kanonska primjenjivost i hijerarhijsko ustrojstvo Crkve, na vidjelo izlazi cjelokupna kompleksnost problematike. Ipak, nakon Drugoga vatikanskoga koncila nestaje dihotomije između crkvenoga autoriteta i vjerničke poslušnosti. Prava vjernika lišena su ideološko-svjetovnoga tumačenja te im je pružen njihov izvorni značaj.

\section{Povijesni pregled razvoja osobnih prava u Crkvi}

\subsection{Prava vjernika prije Drugoga vatikanskoga koncila}

Generalno se osobna prava definiraju kao skup prava što ih, u ovom slučaju, vjernik ili član Katoličke crkve uživa kao pojedinac, a to su u prvom redu nepovredivost i osobne slobode. Upravo su nepovredivost i osobne slobode, kao karakteristike osobnih prava, obilježili njihov povijesni razvoj u pravnom uređenju Crkve. Pitanje o kojem su dvojili crkveni pravnici, ali i fundamentalni teolozi, odnosilo se je na odnos osobnih prava vjernika, uz njih vezane individualne slobode, te koncept hijerarhijskoga ustrojstva Crkve, prema kojem su vjernici laici pasivni subjekti, čije je pravo, u prvom redu, primati duhovna dobra od strane klerika. ${ }^{1}$ Tako je Wernz razlažući etimologiju termina "laici" ustvrdio kako su oni, u strogo terminološkom smislu, vjernici različiti od klera (Wernz, 1899, 15). Ipak, prelazeći s etimološkoga poimanja na njihov pravni položaj, vidi ih kao krštenike koji in gradu quodam imaju svoje mjesto u hijerarhiji Crkve (Wernz, 1899, 14). Prema tome, naglašava krštenje kao zajednički temelj svih vjernika, iako odmah nastavlja te ponovno potvrđuje njihovu različitost u odnosu na kler (Wernz, 1899, 14). Prelazeći konkretno na obveze i prava vjernika, jasno i izričito definira kako laici imaju pravo primati sakramente, prvenstveno smjerajući na ženidbu. Bilo kakvo sudjelovanje u upravnim funkcijama Crkve nije im dopušteno, osim ako u pojedinačnim slučajevima nije predviđeno drugačije (Wernz, 1899, 17).

Zakonik kanonskoga prava iz 1917. priznaje prava koja proizlaze iz krštenja (CIC 2017 kan. 87). Međutim, ta ista prava bila su smještena isključivo u kontekst govora o vjernicima laicima, a čije je pravo primati duhovna dobra od strane klera. Dakle, navedeno pravo bilo je pasivnoga karaktera. Iako o laicima govori treća knjiga Zakonika iz 1917. O osobama kroz 43 kanona (CIC 2017 kann. 682-725), od navedenih čak većina govori o udruženjima vjernika. »Prema tome, samo se dva kanona iz ovoga dijela odnose na laike i to 682. i 683. Kanon 682. priznaje pravo laicima da mogu primati od klerika, prema pravnim propisima,

1 O laicima kao "pasivnim subjektima” usp. Feliciani, 1995. 
duhovna dobra i osobito pripomoći drugima za spasenje. To pravo imaju i klerici, pa ni ono nije samo za laike. Kan. 683. zabranjuje laicima nositi kleričko odijelo« (Delić, 1984, 406). Prema tome, Zakonik kanonskoga prava iz 1917. sadržavao je rigoroznu podjelu vjernika s obzirom na status kojemu su pripadali, koncentrirajući se maksimalno na klerike i redovnike te, s obzirom na to, nije detaljizirao koja su to osobna prava svih vjernika u Crkvi.

Posljedično, na području civilnoga prava postojale su grupacije onih koji su tvrdili kako u pravnom uređenju Crkve ne postoje osobna prava u strogom smislu riječi. Svoju tezu argumentirali su činjenicom javnoga karaktera cjelokupnoga pravnoga uređenja Crkve, u kojem nema prostora za privatna prava, autonomiju, slobode ili osobne interese pojedinaca (Arrieta, 1991, 11-12). S vremenom se je sustav mišljenja počeo mijenjati te tako nastaje sve veći broj znanstvene literature kojom crkveni pravnici pokreću dijalog o postojanju osobnih prava u pravnom uređenju Crkve. Na taj način željeli su, između ostaloga, odgovoriti na optužbe i sumnje o nedovoljnoj brizi Crkve za prava unutar vlastitoga uređenja, uz istovremeno podržavanje poštivanja ljudskih prava. Naime, upravo su brojni poticaji promocije i zaštite ljudskih prava utjecali na bitan pomak Crkve, koja je započela isto po pitanju prava vjernika u Crkvi.

\subsection{Drugi vatikanski koncil: dostojanstvo i prava vjernika}

Već je dvadesetak godina prije koncila započeo govor o temeljnim pravima vjernika, interpretirajući ih pod vidom prava koja je Bog darovao čovjeku na temeljima njegove naravi (Ciprotti, 1942, 276-281). Drugi vatikanski koncil bez sumnje je označio jednu novu fazu kanonskoga prava, koja se na poseban način odražava upravo u materiji osobnih prava u Crkvi. Spomenuti iskorak vidljiv je iz cjelokupnoga koncilskoga nauka, koji u svoj centar stavlja upravo zajedničko dostojanstvo i slobodu djece Božje (LG 9). Na poštivanje prava vjernika izričito upućuje dogmatska konstitucija o Crkvi Lumen genitum razlažući odnos laika i hijerarhije, gdje piše: »A sveti pastiri neka priznaju i promiču dostojanstvo i odgovornost laika u Crkvi; neka se rado posluže njihovim razboritim savjetom, s povjerenjem neka im povjere dužnosti u služenju Crkvi te im ostave slobodu i prostor djelovanja, štoviše neka ih ohrabruju da se i na vlastitu pobudu daju na posao« (LG 37). Tako je konstitucija, po prvi puta, postavila doktrinarni temelj za prevladavanje dotadašnje slike strogo hijerarhijskoga ustrojstva Crkve.

Nastavno na istu tematiku, Dekret o apostolatu vjernika laika također promiče osobna prava vjernika naglašavajući važnu ulogu laičkoga apostolata. Obveze i prava laika na apostolat proizlaze upravo iz njihova jedinstva sa Kristom (AA 3). ${ }^{2}$ Tako je i prilikom obilježavanja pedesete godišnjice od toga dekreta Sveti Otac Franjo još jednom ustvrdio kako vjernici laici nisu samo pasivni izvršitelji zapovijedi hijerarhije, nego su pozvani nadahnjivati svaku sredinu evanđeoskim duhom (Franjo, 2015). 
Uz dva najvažnija dokumenta koncila koji promiču prava i obveze vjernika laika, potrebno je naglasiti kako se ista tematika uočava i u drugim dokumentima. Tako primjerice Konstitucija o svetoj liturgiji Sacrosanctum concilium spominje pravo i obvezu aktivnoga sudjelovanja u sv. liturgiji (SC 14, 1). Pastoralna konstitucija o Crkvi u suvremenom svijetu Gaudium et spes ističe pravo vjernika na teološku formaciju te pravo na slobodu istraživanja i naučavanja (GS 62, 7; usp. Hinder, 1977, 98-101).

Nedvojbeno je ustvrditi kako vjernik, svojim dostojanstvom i slobodom stečenom krštenjem, postaje protagonist prava Crkve nakon Drugoga vatikanskoga koncila. Bez ikakvoga negiranja ili umanjivanja važnosti hijerarhijskoga ustrojstva Božjega naroda, koncil je potvrdio autonomiju i odgovornu slobodu vjernika u Crkvi. Nakon Drugoga vatikanskoga koncila, kanonistička doktrina obrađivala je pitanja vezana uz prava vjernika koristeći i jačajući sve više koncept temeljnih prava vjernika. Primarne teme odnosile su se na narav prava, odnos i povezanost s pravima ljudske osobe u svjetovnom društvu te načine aplikacije, promicanja i zaštite prava. Nastojale su se "pomiriti" i dvije naizgled suprotstavljene strane: prava vjernika s posljedičnom slobodom i autonomijom te crkveni autoritet koji zahtijeva poslušnost.

Nova ekleziologija koncila, iako jasno formulirana, sadržavala je dvije potencijalne opasnosti. Prvenstveno, mogućnost ostanka na razini pukoga formalizma bez promjena na praktičnom planu. S druge strane, opasnost stvaranja dojma ukidanja razlike između klerika, redovnika i laika. Nužno je, nadalje, naglasiti i kako govor o osobnim pravima vjernika ne podrazumijeva u prvom redu samo laike. Upravo bi se takvim krivim tumačenjem povrijedila jednakost svih vjernika pretpostavljena svakoj razlici. ${ }^{3}$ Naime, tek kada se opće svećenstvo i jednakost svih vjernika shvati kao prisutnost Crkve u sadašnjosti i budućnosti krštenika te se život svakoga kršćanina shvati kao slika Crkve u odnosu prema drugima, moguće je shvatiti i suštinu onoga što definira kan. 210 Zakonika kanonskoga prava (Cardia, 2010, 120).

Koncil nije definirao ni formulirao svojevrsni popis obveza i prava vjernika. Štoviše, ne ulazi u definiranje elemenata na temelju kojih bi se mogla stvoriti sinteza i prikazati odnos između ljudskih prava i prava vjernika. Ipak, navedena praznina nadvladana je već pri reviziji Zakonika kanonskoga prava iz 1917. godine. Tako Sinoda biskupa, održana 1967. godine, među prvotnim elementima reforme navodi upravo priznanje i zaštitu prava vjernika. ${ }^{4}$

3 To je ujedno i načelo koje je nadahnjivalo obnovu Zakonika kanonskoga prava: »Et quoniam non omnes eamdem functionem in Ecclesia habent, neque idem statutum omnibus convenit, merito proponitur un in futuro Codice ob radicalem aequalitatem quae inter omnes christifideles vigere debet, tum ob humanam dignitatem tum ob receptum baptisma, statutum iuridicum omnibus commune condatur, antequam iura et officia recenseantur quae ad diversas ecclesiasticas functiones pertinent « (Communicationes 1(1969) 83).

4 »Unicuique christifidelium iura agnoscenda ac tuenda sunt, et quae in lege naturali vel divina positive continentur, et quae ex illis congruenter derivantur ob insitam socialem conditionem quam in Ecclesia acquirunt et possident [...]ut in futuro Codice ob radicalem aequalitatem quae inter omnes christifideles vigere debet, tum ob humanam dignitatem tum ob receptum baptisma, 
Prilikom reforme Zakonika kanonskoga prava dvije su komisije bile zadužene za formuliranje popisa prava vjernika: coetus de laicis i coetus de Lex Ecclesiae Fundamentalis. Prijedlog sastavljen od strane skupine de laicis odbačen je jer je planirana objava Legis Ecclesiae Fundamentalis. Međutim, kako do objave istoga nije došlo, sukladno odluci Svetoga Otca, odlučeno je unutar druge knjige reformiranoga Zakonika kanonskoga prava uvrstiti i kanone o obvezama i pravima vjernika.

\section{Obveze i prava vjernika u Zakoniku kanonskoga prava}

Zakonik kanonskoga prava iz 1983. po prvi puta formalizira popis prava i obveza zajedničkih svim vjernicima pod dva naslova: Obveze i prava svih vjernika (CIC kann. 208-223) i Obveze i prava vjernika laika (CIC kann. 224-231).

Do sada rečeno sažeto je u sljedećem: »Među svim vjernicima, upravo po njihovu preporođenju u Kristu, s obzirom na dostojanstvo i djelovanje vrijedi istinska jednakost kojom svi, svatko prema svojem položaju i službi, sudjeluju u izgradnji Kristova Tijela « (CIC kann. 208). ${ }^{5}$

S obzirom na strukturu sadržaja evidentni su sljedeći elementi: Kao prvo, nisu regulirana samo prava, nego i obveze vjernika. Nadalje, popis obveza i prava vjernika nije odviše iscrpan. Ne praveći distinkciju između prava čovjeka i prava vjernika te bez određena sistematskoga reda, formulirana je serija obveza i prava za koje je smatrano kako u najvećoj mjeri odgovaraju strukturi i ustrojstvu crkvene zajednice. Dakle, riječ je o popisu koji daje mjerodavne indikacije otvorene konstruktivnomu tumačenju kanonske doktrine (usp. Ghirlanda, 1984).

Zanimljivo je uočiti kako Zakonik ne koristi termin temeljna prava vjernika. Isto pak ne znači da se osobnim pravima vjernika negira svojevrsna "utemeljenost", nego se je samo nastojalo ukazati kako ona trebaju i moraju biti utemeljena i interpretirana u svjetlu kanonske doktrine. Prema tome, ne mogu se interpretirati jednako kao temeljna (osobna) prava članova civilnoga društva. Na pravima vjernika temelji se autonomija svakoga pojedinoga člana zajednice te, potom, zajednice kao takove. Ipak, riječ je o autonomiji koja se nužno mora integrirati uz zajednicu kojoj svaki pojedini vjernik pripada (Felicani, 1995, 121-123).

\subsection{Nositelji osobnih prava u Crkvi}

Nositelji osobnih prava u Crkvi svi su vjernici kršteni u Katoličkoj crkvi, kako je izričito navedeno: »Čovjek se krštenjem pritjelovljuje Kristovoj Crkvi i postaje

statutum iuridicum omnibus commune condatur, antequam iura et officia recenseantur quae ad diversas ecclesiasticas functiones pertinent « (Communicationes 1(1969) 82-83; usp. Beyer, 1968; Lombardia, 1969).

5 O tendencijama ukidanja ikakve razlike između vjernika klerika, redovnika i laika te uspostavljanja samo jednoga statusa, statusa vjernika, usp. Parlato, 1993. Kako navodi Ghirlanda (2004, 20), termin status ne označava Crkvu kao societas inequalium i različiti položaji vjernika u Crkvi ne smiju se tumačiti pod vidom "klasa". 
u njoj osoba, s dužnostima i pravima koja su kršćanima, uzevši dakako u obzir njihov položaj, vlastita, ako su u crkvenom zajedništvu i ako to ne priječi zakonito donesena kaznena mjera (CIC kan. 96). Regulirajući pravni status krštenika, Zakonik kanonskoga prava koristi dva međusobno povezana termina, a to su osoba i vjernik kršćanin. Pravni status osobe formalna je kategorija (CIC kan. 96). S druge strane, vjernik kršćanin teološka je kategorija, formulirana na Drugom vatikanskom koncilu (Lo Castro, 1985, 13-99). Ipak, kako tvrdi Ghirlanda (2004, 8), i vjernik i osoba izražavaju jednaku stvarnost. Krštenjem čovjek stječe novu subjektivnost u ekonomiji spasenja, ako je inkorporiran u Krista i Crkvu, a posljedično i specifičnu subjektivnost unutar crkveno-pravnoga uređenja.

Drugim riječima, kanon 96 izričito je pravnoga karaktera definirajući krštenika kao osobu u Crkvi te kao subiectum iuris. Kanoni $204 \$ 1^{6}$ i 208 teološkoga su karaktera ako definiraju krštenike kao članove Božjega naroda, jednake po dostojanstvu a različite po službama. Na temelju te, teološke, formulacije utvrđene su obveze i prava svih vjernika, razlikujući ih od obveza i prava vjernika laika (Castillo Lara, 1986, 322).

Spomenutim dvama terminima osoba i vjernik kršćanin nipošto se ne želi formulirati temelj pravne osobnosti. Kanonsko zakonodavstvo već prije rođenja priznaje čovjeka kao nositelja temeljnih prava, koja pripadaju svakoj ljudskoj osobi, kao što je pravo na život, obrazovanje, vjerske slobode i dr. (Aymans, 1995).

Iako se krštenjem postaje nositeljem osobnih obveza i prava u Crkvi, ostvarenje istih nije apsolutno ni bezuvjetno. Ostvarivanje i izvršavanje obveza i prava moguće je jedino u potpunom zajedništvu sa Katoličkom crkvom. Upravo je potonje jedan od elemenata koji čine specifičnost prava vjernika u odnosu na ljudska prava.

Čak ni nekrštenim osobama nisu dokinuta njihova prava. Naime, njihov pravni položaj u prvom redu smjera pravu na primanje sakramenta krštenja. To isto pravo u suodnosu je s, isključivo, moralnom obvezom, ${ }^{7}$ isključujući pravnu obvezu te poštujući vjerske slobode. ${ }^{8}$ Isti, također, mogu postati dionicima pravnoga uređenja s nekoga drugoga naslova, kao primjerice u slučaju sklapanja ženidbe s krštenom osobom ili sklapanjem određenih ugovora ekonomsko-imovinskoga karaktera. Spomenuta prava nekrštenih mogu se, naravno, i štiti u skladu s kanonom $1476 .^{9}$

6 »Vjernici su oni koji su, krštenjem pritjelovljeni Kristu, sazdani u Božji narod i zbog toga su, postavši na svoj način dionici Kristove svećeničke, proročke i kraljevske službe, pozvani da, svatko prema svojem položaju, vrše poslanje koje je Bog povjerio Crkvi da ga ispuni u svijetu (CIC kan. 204 §1).

7 »Svi su ljudi dužni tražiti istinu o Bogu i njegovoj Crkvi, a, pošto je spoznaju, snagom božanskoga zakona obvezni su i imaju pravo prigrliti je i čuvati« (CIC kan. 748 §1).

8 »Nikome nikada nije dopušteno prisiljavati ljude da protiv svoje savjesti prigrle katoličku vjeru « (CIC kan. 748 §).

9 »Svatko, bio kršten bio nekršten, može nastupati kao tužitelj; zakonito pak tužena stranka mora odgovarati« (CIC kan. 1476). 
Poseban pak status imaju katekumeni koji izričitom voljom traže pritjelovljenje Crkvi. Prema Zakoniku kanonskoga prava, oni uživaju različite pogodnosti vlastite kršćanima (CIC kan. 206). ${ }^{10}$

\subsection{Ograničenja osobnih prava vjernika}

Osobna prava vjernika nisu apsolutna niti subjektima osiguravaju apsolutnu autonomiju u odnosu na zajednicu. Ograničenja prava vjernika, interna i eksterna, točno su određena unutar Zakonika, prema kojem: »U vršenju svojih prava vjernici i pojedinačno i okupljeni u društvima moraju voditi računa o zajedničkom dobru Crkve, o pravima drugih i o svojim dužnostima prema drugima« (CIC kan. 223 \$1). Prema tome, opće dobro, prava drugih i dužnosti prema drugima postavljena su kao interno ograničenje. S druge strane, eksterno ograničenje uređeno je na sljedeći način: »Crkvenoj vlasti pripada da uredi, imajući na umu zajedničko dobro, vršenje prava koja su vlastita vjernicima« (CIC kan. 223 §2). Drugim riječima, crkvena vlast ima pravo ograničiti određena prava u korist zajedničkoga ili općega dobra. Upravo je to eksterno ograničenje izazvalo prijepore doktrine. Naime, nije navedeno kako, kojim je metodama i sredstvima dopušteno crkvenoj vlasti regulirati ostvarivanje prava vlastitih vjernicima.

Bitno je napomenuti kako ipak nisu sva prava podložna ograničenjima. Jedno od takvih zasigurno je pravo izbora životnoga staleža (CIC kan. 219), koje ni u kojem slučaju ne može biti ograničeno u korist zajedničkoga ili općega dobra (Arrieta, 1991, 28).

Uz ograničenja, u crkvenom pravu postoje i mehanizmi zaštite osobnih prava: »Vjernicima pripada da prava koja u Crkvi imaju zakonito zahtijevaju i prema pravnoj odredbi štite na mjerodavnom crkvenom sudu « (CIC kan. 221 §1). Schema Legis Ecclesiae Fundamentalis detaljno je predlagala mehanizme zaštite osobnih prava, i to preko mjerodavnih crkvenih sudova, upravnih sudova ili putem određene odluke suda, koji bi povredu zakona i opće administrativne odluke proglasio nekonstitutivnim (Mirabelli, 1981, 397-418). Budući da je funkcija crkvenih sudova danas prvenstveno usmjerena ženidbenim postupcima, u određenoj mjeri trebalo bi promisliti o mogućnostima aktivnije zauzetosti u sporovima povrede osobnih prava. Nadalje, kako određeni broj sporova nastaje između pojedinaca i izvršne vlasti, te vrste povreda ne bi smjele biti svedene isključivo na Apostolsku signaturu (Arrieta, 1991, 32).

Osim sudova, Zakonik predviđa i utoke protiv upravnih odluka (CIC kann. 1732-1739) ako opravdani razlog utoka hijerarhijskomu poglavaru može biti upravo povreda određenoga osobnoga prava.

10 O pravnom položaju katekumena usp. Urrutia, 1974 


\section{Odnos osobnih prava vjernika i ljudskih prava}

Pastoralna konstitucija o Crkvi navodi: »Radost i nada, žalost i tjeskoba ljudi našeg vremena, osobito siromašnih i svih koji trpe jesu radost i nada, žalost i tjeskoba također Kristovih učenika, te nema ničega uistinu ljudskoga a da ne bi našlo odjeka u njihovu srcu. Kršćansku zajednicu naime sačinjavaju ljudi, koje u Kristu sjedinjene vodi Duh Sveti na njihovu hodu prema Očevu Kraljevstvu. Oni su primili poruku spasenja da je iznesu pred svakoga. Zato zajednica kršćana doživljava sebe doista usko povezanom s ljudskim rodom i s njegovom poviješću « (GS 1).

Uvodna točka konstitucije predstavlja opće načelo, koje svoju praktičnu primjenu pronalazi upravo u Općoj deklaraciji o ljudskim pravima. Prava sadržana unutar spomenute deklaracije karakterizira univerzalnost, nepodijeljenost i međuovisnost. ${ }^{11}$ Upravo je potvrđivanje temeljnih prava čovjeka potaknulo kršćansku zajednicu na preispitivanje prava vjernika u kanonskom uređenju. Temeljni cilj nije bio jednostavno potvrđivanje prava ljudske osobe, stvorene na sliku Božju, nego izdvojiti i nominalno konkretizirati osobna prava vjernika (Lorusso, 2009, 167).

Unatoč pozitivnomu poticaju svjetovne strane, ipak je nužno naglasiti kako temelj i narav prava vjernika nije istovjetna pravima građana općenito. Razlog tomu treba potražiti u činjenici prema kojoj postoje objektivne razlike između Crkve i društva te različit pristup shvaćanju odnosa pojedinca i zajednice. Dovoljno je reći kako u Crkvi nije moguće odvajati privatno i opće dobro, jer se svaki pojedinac ostvaruje upravo u okrilju zajednice kojoj pripada. Jednako tako, Crkva različito poima i sam koncept slobode jer, za razliku od laičke i racionalističke kulture, svakoga vjernika promatra u njegovoj izvornoj zavisnosti o Bogu (Lorusso, 2009, 166).

Gore navedena različitost ipak ne znači da Crkva daje prednost pravima vjernika nasuprot temeljnim ljudskim pravima. Od samih početaka, crkvene i vjerske institucije poticale su edukaciju koja bi za cilj imala promoviranje i zaštitu ljudskih prava. Doprinos Crkve po tom pitanju konkretizira se kroz kontinuiranu i permanentnu edukaciju, prije svega, samih članova Crkve. Ona za prvotni cilj ima osvijestiti pojedince o važnosti i ulozi ljudskoga dostojanstva, jednakosti i slobode, a upravo su to vrijednosti vlastite svakomu ponaosob. Za drugotni cilj postavlja se rađanje i razvijanje volje za poštivanjem tih istih temeljnih prava u svakodnevnom životu (Biskupska sinoda, 1971, 933-934).

11 O univerzalnom i nedjeljivom karakteru ljudskih prava Ivan Pavao II. govorio je povodom Svjetskoga dana mira 1998. godine. Napominjući kako se vrlo često kršenje ljudskih prava opravdava "specifičnošću" pojedinih kultura, Sveti Otac doziva u svijest njihov univerzalni i nedjeljivi karakter, koji ne dopušta manipulaciju istima (Ivan Pavao II., 1998). Detaljnije o teorijskom, pastoralnom i političkom doprinosu Svetoga Otca tematici ljudskih prava usp. Kujundžija, 2000, 279-286. 
Ipak, djelovanje Crkve ne ide samo u smjeru promicanja ljudskih prava, nego i u osvješćivanju obveza prema drugima (DH 8). ${ }^{12}$ Zaključno, neosporno je kako Crkva igra veliku ulogu u promicanju temeljnih ljudskih prava ukazujući kako postoje drugi i drugačiji, s kojima smo nužno vezani u svakodnevnom životu. Štoviše, odgajati za poštivanje ljudskih prava znači odgajati za poštivanje različitosti mišljenja i djelovanja drugih, kojima često pristupamo s predrasudama (Papinsko vijeće za pravdu i mir, 1975, 63-64).

\subsection{Zajednički elementi}

Unatoč tomu što su prava vjernika, navedena u Zakoniku kanonskoga prava, specifično kršćanskoga karaktera, postoje i određena prava koja su specifično ljudska, pripadaju svakomu pojedincu. Upravo su to ona koja u svjetovnom pravnom uređenju nazivamo temeljnim ljudskim pravima. Neka od tih su: pravo na slobodno udruživanje (CIC kan. 215); ${ }^{13}$ pravo na slobodu istraživanja i mišljenja (CIC kan. 218); ${ }^{14}$ pravo na dobar glas (CIC kan. 220); ${ }^{15}$ pravo na obranu i zaštitu prava (CIC kan. 221; usp. Ujedinjeni narodi, 2009, čl. 7-11); pravo vjernika laika na pravičnu naknadu za vršenje crkvenih služba (CIC kan. 231 §2). ${ }^{16}$ Navedenomu svakako možemo dodati i pravo na sklapanje ženidbe (CIC kan. 1058). ${ }^{17}$

Slobodno je stoga zaključiti kako osobna prava vjernika u određenoj mjeri (ne apsolutno) pretpostavljaju i temeljna ljudska prava koja, kako je već rečeno, imaju svoj izvor u kršćanskoj misli o naravnom pravu. Pravno uređenje Crkve respektira moralnu i pravnu vrijednost naravnih prava. Ipak, čisto mehaničko preuzimanje ljudskih prava, onako kako ih regulira Opća deklaracija o ljudskim pravima, ustavi modernih država i drugi dokumenti, nije moguće. Prvotni razlog njihovi su ideološki korijeni nespojivi s načelima kanonskoga ustrojstva (Sikirić, 2000, 327). Zato je opravdano zaključiti kako postoje prava čovjeka i prava kr-

12 Kako ističe fra Miron Sikirić, upravo je saborska deklaracija Dignitatis humanae »doživljena kao svojevrsni 'kopernikanski' obrat u stajalištu Crkve s obzirom na ljudska prava i njezino poimanje društva i države« (Sikirić, 2000, 325).

13 »1. Svatko ima pravo na slobodu mirnog okupljanja i udruživanja. 2. Nitko se ne smije prisiljavati na pripadanje nekoj udruzi« (Ujedinjeni narodi, 2009, čl. 20).

14 »Svatko ima pravo na slobodu mišljenja i izražavanja; to pravo uključuje slobodu zadržavanja mišljenja bez uplitanja i slobodu traženja, primanja i širenja informacija i ideja putem bilo kojeg medija i bez obzira na granice« (Ujedinjeni narodi, 2009, čl. 19).

15 »Nitko ne smije biti podvrgnut samovoljnom miješanju u njegov privatni život, obitelj, dom ili dopisivanje, niti napadima na njegovu čast i ugled. Svatko ima pravo na zakonsku zaštitu protiv takvog miješanja ili napada« (Ujedinjeni narodi, 2009, čl. 12).

16 »Svatko tko radi ima pravo na pravednu i primjerenu naknadu koja njemu i njegovoj obitelji osigurava život dostojan čovjeka i koja se prema potrebi dopunjuje drugim sredstvima socijalne zaštite« (Ujedinjeni narodi, 2009, čl. 23, §3).

17 »1. Punoljetni muškarci i žene imaju pravo stupiti u brak i osnovati obitelj bez ikakvih ograničenja glede rase, državljanstva ili vjeroispovijedi. Oni su ovlašteni na ista prava prilikom sklapanja braka, u braku i tijekom razvoda. 2. Brak se može sklopiti samo uz slobodan i potpun pristanak osoba koje namjeravaju stupiti u brak. 3. Obitelj je prirodna i temeljna društvena jedinica te je ovlaštena na zaštitu društva i države« (Ujedinjeni narodi, 2009, čl. 16, §§1-3). 
šćanina, sa svim svojim specifičnostima. Nužno je stoga izbjegavati »nekritička pravna prihvaćanja, protivna biti Crkve« (Sikirić, 2000, 335).

\subsection{Specifičnost prava vjernika}

Unatoč utemeljenosti na naravnom pravu, prava vjernika ne mogu se u potpunosti izjednačiti s temeljnim ljudskim pravima. Njihov prvotni temelj ipak proizlazi iz inkorporacije u Narod Božji. Jednako bi tako krivo bilo ustvrditi kako preegzistiraju u Crkvi jer ih Crkva podjeljuje krštenjem i ostalim sakramentima. Nadalje, prvotni cilj Crkve nije sveden na garanciju i zaštitu osobnih prava vjernika, niti prava pojedinaca pretpostavlja općemu dobru. Sve navedeno razlog je tomu zašto pojedini crkveni pravnici izbjegavaju korištenje termina "temeljna" prava vjernika pod vidom osobnih prava normiranih u aktualnom Zakoniku kanonskoga prava (Ruoco Varela, 1981, 53-55).

Vrednujući temeljna ljudska prava, Crkva je oduvijek nastojala ukazati na nužan odnos prava i obveza, kako se može iščitati, između ostaloga, i iz govora Svetoga Otca Pavla VI. prilikom dvadeset i pete obljetnice od proglašenja Deklaracije o ljudskim pravima. Sveti Otac ističe kako temeljna ljudska prava predstavljaju opće dobro čitavoga čovječanstva te je nužno da svi ljudi, svjesni te činjenice, prihvate i obvezu njihova poštivanja (Pavao VI., 1973, 677). Naglašavanje ispunjavanja obveza kao preduvjeta ostvarivanja prava sastavni je dio i svjetovne prakse. Prema tome, svijest pojedinca o temeljnim obvezama platforma je poštivanja prava svakoga pojedinoga člana društva.

Razmatrajući odnos temeljnih ljudskih prava i osobnih prava vjernika, nemoguće je ne dotaknuti pitanje vjerske slobode u kontekstu kanonskoga prava. Pravo je to često puta aktualizirano na Drugom vatikanskom koncilu, napose u deklaraciji o vjerskoj slobodi Dignitatis humanae. ${ }^{18}$ Isto je potvrdila i Međunarodna teološka komisija u dokumentu objavljenom 2019. godine pod naslovom La libertà religiosa per il bene di tutti. Upravo taj dokument nastoji aktualizirati načela spomenute Deklaracije. Budući da Crkva uvelike poštuje vjerske slobode osoba koje nisu vjernici, svojevrsna relativizacija toga istoga prava krštenim članovima Crkve ne čini se opravdanom. Ipak, temeljna poteškoća priznavanja vjerske slobode krštenim vjernicima u neposrednoj je vezi s, već spomenutom, pravnom obvezom zajedništva - ispovijedanje vjere, sakramenata i poslušnost hijerarhiji. Potencijalno rješenje nudi kanonski pravnik Juan Ignacio Arrieta. On razlikuje dva tipa interpretacije "vjerske slobode". U užem smislu, ona je vezana uz položaj pojedinca u civilnom društvu, koje ne postavlja nikakve formalne obveze u materiji religije. Drugo, šire tumačenje, odnosi se na slobodan odgovor svakoga pojedinca obvezama koje religija koju je prigrlio podrazumijeva. U prav-

18 »Ovaj Vatikanski koncil izjavljuje da ljudska osoba ima pravo na slobodu vjerovanja. Takva se sloboda sastoji u tome da svi ljudi moraju biti izuzeti od pritiska bilo pojedinaca bilo društvenih skupina i bilo koje ljudske vlasti, i to tako da u stvarima vjerovanja nitko ne bude niti primoravan postupati protiv svoje savjesti niti sprječavan postupati po svojoj savjesti, privatno i javno, bilo sam bilo udružen s drugima, unutar dužnih granica« (DH 2). 
nom smislu, takva interpretacija vjerske slobode znači neprihvatljivost prisile u izvršavanju vjerskih obveza. Jedino u tom potonjem tumačenju moguće je govoriti o vjerskoj slobodi u kanonsko-pravnom smislu (Arrieta, 1991, 50-51).

\section{Zaključak}

Drugi vatikanski koncil polučio je znatan iskorak u shvaćanju i tumačenju osobnih prava vjernika utoliko što je potvrdio temeljnu jednakost svih članova Crkve. Oslobodivši osobna prava ideološkoga tumačenja, kao ona koja veličaju individualne slobode na štetu zakona države, društva i Crkve, promijenio je i dotadašnju interpretaciju ne samo osobnih prava vjernika, nego i ljudskih prava. Isto je vidljivo napose iz enciklike pape Ivana XXIII. Pacem in terris, ali i iz drugih sličnih intervenata crkvenoga učiteljstva. Tako je, na tragu poruke pape Pavla VI. (1973), u svojem govoru o 60-oj obljetnici Deklaracije o ljudskim pravima, 22. listopada 2008. mons. Francesco Follo (2008), stalni promatrač Svete Stolice pri Unescu istaknuo kako je upravo ona jedna od najljepših plodova konvergencije različitih kultura i tradicija te kako je važno sredstvo zaštite ljudske osobe i njezina dostojanstva. Iako osobna prava vjernika i ljudska prava sadržajno počivaju na istom korijenu, ljudskom dostojanstvu, nemoguće je ne uočiti različitosti koje ih čine autentičnima. Ljudska prava počivaju na naravnom pravu, a osobna prava vjernika proizlaze iz inkorporacije u Narod Božji. Štoviše, ona ne pre-egzistiraju u Crkvi, nego se stječu krštenjem, kada postajemo punopravni članovi Crkve, ali i primanjem ostalih sakramenata. Prava vjernika nikada nisu odijeljena od pripadajućih obveza, i upravo je izvršavanje obveza garancija ostvarivanja odnosnih prava. Nadalje, zajednica i opće dobro pretpostavke su ostvarivanja osobnih prava vjernika te se nikako osobno dobro i osobno pravo ne može zahtijevati na štetu općega. Crkva je svjesna kako se u velikoj mjeri ljudska prava većega broja ljudi zapostavljaju i krše u ime slobode pojedinca te je kao takva pozvana ostvarivati svoju proročku službu i apelirati na poštivanje onih prava kojima je temelj ljudsko dostojanstvo. Tomu zadatku zasigurno pristupa i pristupat ce i nadalje vođena načelom vlastita koncepta slobode, a to je onaj koji čovjekov izvor pronalazi u Bogu. Podršku u tom zadatku zasigurno čini i Opća deklaracija o ljudskim pravima. Upravo je ona od elementarne važnosti za izgradnju zdrave svijesti i morala u skladu s dostojanstvom svakoga pojedinca, člana zajednice.

\section{Literatura}

AA. Apostolicam actuositatem. (28. listopada 1965.) Drugi vatikanski koncil, Dekret Apostolicam actuositatem o apostolatu laika. U: Josip Turčinović (ur.), II vatikanski koncil: Dokumenti: Latinski i hrvatski (str. 418-466). Zagreb: Kršćanska sadašnjost, 1970.

Arrieta, Juan Ignacio (1991). I diritti dei soggetti nell'ordinamento canonico. Fidelium Iura, 1, 9-46.

Aymans, Winfried (1995). Lo statuto dei diritti dell'uomo nell'ordinamento giuridico ecclesiale. Il Diritto Ecclesiastico, 106, 15-34. 
Beyer, Jean (1968). De statuto iuridico christifidelium iuxta vota synodi episcoporum in novo codice condendo. Periodica, 57, 550-581.

Biskupska sinoda (1971). Giustizia nel mondo. Acta Apostolicae Sedis, 63(1), 923-942.

Cardia, Carlo (2010). La Chiesa tra storia e diritto. Torino: Giappicheli.

Castillo Lara, Rosalio (1986). I doveri ed i diritti dei "christifideles". Salesianum, 48, 307-329.

CIC 1917. Codex Iuris Canonici 1917. U: Codex Iuris Canonici fontium annotatione auctus MDCCCCXVII: Kodeks kanonskog prava s izvorima 1917.: Uređen po odredbi sv. oca pape Pija X., proglašen po nalogu pape Benedikta XV. Zagreb: Glas Koncila, 2007.

CIC. Codex Iuris Canonici. Ivan Pavao II., Zakonik kanonskoga prava. Zagreb: Glas Koncila, 1996.

Ciprotti, Pio (1942). Personalità e battesimo nel diritto della Chiesa. Il Diritto Ecclesiastico, 53, 276-281.

Delić, Josip (1984). Prava i dužnosti vjernika laika. Bogoslovska smotra, 54(2-3), 404-413.

DH. Dignitas humanae. (7. prosinca 1965.) Drugi vatikanski koncil, Deklaracija Dignitas humanae o vjerskoj slobodi. U: Josip Turčinović (ur.), II vatikanski koncil: Dokumenti: Latinski i hrvatski (str. 468-489). Zagreb: Kršćanska sadašnjost, 1970.

Feliciani, Giorgio (1995). I diritti e i doveri dei fedeli nella codificazione postconciliare. Quaderni di diritto ecclesiale, 8, 255-271.

Follo, Francesco (2008). Sui diritti umani, nessun cedimento a "interpretazioni relativistiche". Zenit, 23. listopada 2008. URL: https:/it.zenit.org/articles/sui-diritti-umaninessun-cedimento-a-interpretazioni-relativistiche/ (13. travnja 2020.)

Franjo (2015). Occasione del 500 anniversario del decreto Apostolicam actuositatem. Acta Apostolicae Sedis, 108(12), 1328-1329.

Ghirlanda, Gianfranco (1984). De obligationibus et iuribus christifidelium in communione ecclesiali deque eorum adimpletione et exercitio. Periodica, 73, 328-378.

Ghirlanda, Gianfranco (2004). Diritti fondamentali e carismi nella Chiesa. U: I diritti fondamentali del fedele: A venti anni dalla promulgazione del Codice (str. 7-28). Città del Vaticano: Libreria Editrice Vaticana.

GS. Gaudium et spes. (7. prosinca 1965.) Drugi vatikanski koncil, Pastoralna konstitucija Gaudium et spes o Crkvi u suvremenom svijetu. U: Josip Turčinović (ur.), II vatikanski koncil: Dokumenti: Latinski i hrvatski (str. 620-768). Zagreb: Kršćanska sadašnjost, 1970.

Hinder, Paul (1977). Grundrechte in der Kirche: Eine Untersuchung zur Begründung der Grundrechte in der Kirche. Freiburg: Universitätsverlag.

Ivan Pavao II. (1998). Messaggio per la giornata mondiale della pace. Enchiridion Vaticanum, 16, 1515.

Kujundžija, Zdravko (2000). Dostojanstvo osobe i ljudska prava i slobode u naučavanju Ivana XXIII, Pavla VI. i Ivana Pavla II. U: Velimir Blažević (ur.), Ljudska prava i Katolička Crkva (str. 265-287). Sarajevo: Pravni centar.

LG. Lumen genitum. (21. studenoga 1964.) Drugi vatikanski koncil, Dogmatska konstitucija Lumen genitum o Crkvi. U: Josip Turčinović (ur.), II vatikanski koncil: Dokumenti: Latinski i hrvatski (str. 91-204). Zagreb: Kršćanska sadašnjost, 1970.

Lo Castro, Gaetano (1985). Il soggetto e i suoi diritti nell'ordinamento canonico. Milano: Giuffrè.

Lo Castro, Gaetano (2011). Il mistero del diritto: II. Persona e diritto nella Chiesa. Torino: Giappichelli. 
Lombardia, Pedro (1969). I diriti fondamentali del fedele. Concilium, 5(8), 103-111.

Lopez Alarcon, Mariano (1969). El abuso del derecho en el ordenamiento canónico. Ius Canonicum, 17(9), 121-155.

Lorusso, Lorenzo (2009). I diritti e i doveri dei fedeli cristiani nel Codex Canonum Ecclesiarum Orientalium e nel Codex Iuris Canonici. Iura Orientalia, 5, 166-184.

Mirabelli, Cesare (1981). La protezione giuridica dei diritti fondamentali. U: Eugenio Corecco et al. (ur.), I diritti fondamentali del cristiano nella Chiesa e nella società: Atti del IV Congresso Internazionale di Diritto Canonico (str. 397-418). Milano.

Papinska komisija za autentično tumačenje zakonodavnih tekstova (1969), Communicationes, I, 77-85.

Papinsko vijeće za pravdu i mir (1975). La Chiesa e i diritti dell'uomo. Città del Vaticano.

Parlato, Vittorio (1993). Status, II) Diritto canonico. U: Giovanni Treccani (ur.), Enciclopedia giuridica (str. 1-5). Roma.

Pavao VI. (1973). Messaggio all'ONU in occasione del XXV anniversario della Dichiarazione Universale dei Diritti dell'Uomo, 10 dicembre 1973. Acta Apostolicae Sedis, 65, 673-677.

PT. Pacem in terris. Ivan XXIII., Pacem in terris: Encikličko pismo [...] o miru svih naroda što ga je utemeljiti na istini, pravednosti, ljubavi i slobodi. U: Marijan Valković (ur.), Socijalni dokumenti Crkve: Sto godina katoličkoga socijalnog nauka (str. 163-202). Zagreb: Kršćanska sadašnjost, 1991.

Ruoco Varela, Antonio (1981). Fundamentos eclesiológicos de una teoría general de los derechos fundamentales del cristiano en la Iglesia. U: Eugenio Corecco et al. (ur.), I Diritti Fondamentali del Cristiano nella Chiesa e nella Società: Atti del IV Congresso Internazionale di Diritto Canonico (str. 53-78). Milano.

SC. Sacrosanctum concilium. (4. prosinca 1963.) Drugi vatikanski koncil, Konstitucija Sacrosanctum concilium o svetoj liturgiji. U: Josip Turčinović (ur.), II vatikanski koncil: Dokumenti: Latinski i hrvatski (str. 8-71). Zagreb: Kršćanska sadašnjost, 1970.

Sikirić, Miron (2000). Temeljna ljudska i vjernička prava u ustrojstvu i zakonodavstvu Crkve. U: Velimir Blažević (ur.), Ljudska prava i Katolička Crkva (str. 316-342). Sarajevo: Pravni centar.

Ujedinjeni narodi (2009). Opća deklaracija o ljudskim pravima usvojena i proglašena od Opće skupštine Rezolucijom 217 A (III) 10. prosinca 1948. Narodne novine, br. 12, dokument br. 143.

Urrutia, Francisco Javier (1974). Catechumenatus iuxta Concilium oecumenicum Vaticanum secundum. Periodica, 63, 121-144.

Wernz, Franz Xavier (1899). Ius decretalium ad usum praelectionum in scholis textus canonici sive iuris decretalium: Vol. 2: Ius constitutionis ecclesiae catholica. Roma: Prati. 
The Relationship between the Rights of the Christian Faithful and Human Rights Marija Džinić*

Summary

The regulation in the Church of the rights of the Christian faithful is one of the greatest milestones of the Code of Canon Law. The Second Vatican Council had a great effect on the raising of this issue. The documents of the Council speak very clearly about the requirement to respect, not only the obligations of the faithful in the Catholic Church, but also their rights.

No less significant was the contribution of the Universal Declaration of Human Rights, a document which focuses on human dignity. The obligation to respect this same dignity is invoked also in the doctrine of the Church. On the basis of an analysis of the relationship between the rights of the Christian faithful and human rights in general, this article endeavours to explain and highlight the similarities and differences between these two systems. Despite the fact that they are grounded in natural law, the rights of the Christian faithful cannot be equated fully with fundamental human rights. Moreover, human rights are based on natural law, while the former arise from their incorporation into the community of the People of God. The Church is aware that human rights today are largely violated in the name of individual freedom. Her mission is to appeal for the respect of those rights, and she is assisted in this task by the Universal Declaration of Human Rights. It is precisely this document that is essential to the process of building a mature and healthy consciousness and morality in accordance with the dignity of each community member.

Key words: rights of the Christian faithful; human rights; Universal Declaration of Human Rights; Second Vatican Council; Code of Canon Law; People of God

* Marija Džinić, Ph.D., Faculty of Philosophy and Religious Studies. Address: Jordanovac 110, 10000 Zagreb. E-mail: m.dzinic@ffrz.hr 